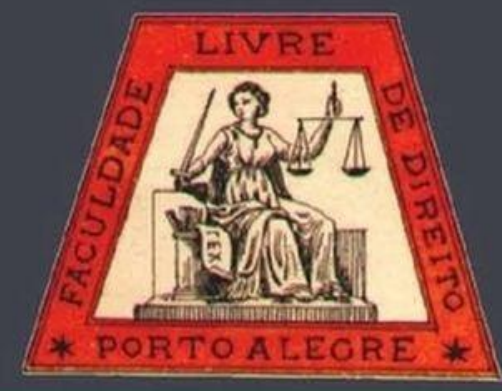

\title{
Questões políticas e Supremo Tribunal Federal: da autolimitação ao moralismo
}

\author{
Political question doctrine and Supreme Federal Court: from \\ autolimitation to moralism
}

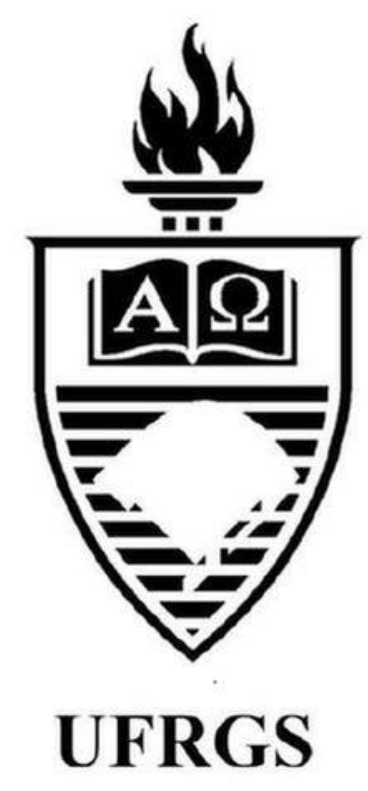

Rômulo Guilherme Leitão

Universidade de Fortaleza

José Patriarca Brandão de Souza

Universidade de Fortaleza 


\title{
Questões políticas e Supremo Tribunal Federal: da autolimitação ao moralismo
}

\author{
Political question doctrine and Supreme Federal Court: from autolimitation to moralism
}

\author{
Rômulo Guilherme Leitão*
}

\author{
José Patriarca Brandão Souza**
}

\begin{abstract}
REFERÊNCIA
LEITÃO, Rômulo Guilherme; SOUZA, José Patriarca Brandão. Questões políticas e Supremo Tribunal Federal: da autolimitação ao moralismo. Revista da Faculdade de Direito da UFRGS, Porto Alegre, n. 39, p. 189-204, dez. 2018.
\end{abstract}

\begin{abstract}
RESUMO
O presente artigo trata das questões políticas no âmbito do Supremo Tribunal Federal a partir de uma perspectiva histórica da matéria. Em que pese a tripartição das funções do Estado, algumas razões históricas levaram ao modelo atual de jurisdição constitucional no Brasil, sendo possível identificar que, desde a Primeira República (1889-1930), o Poder Judiciário é provocado a se manifestar acerca dos limites de sua atuação em temas dessa natureza. Com a promulgação da Constituição de 1988, sob o prisma de uma nova democracia, o quadro institucional brasileiro foi substancialmente alterado a partir do novo paradigma constitucional, ao qual foi atribuído um papel estratégico ao Poder Judiciário conferindo-lhe autonomia funcional com o intuito de impedir que o Direito continuasse a ser instrumentalizado. Dois momentos serão analisados neste trabalho: i) os habeas corpus 300 (1892), 1063 (1898), 1073 (1898) e a obra clássica O Direito do Amazonas ao Acre Setentrional (1910); e ii) a atuação do Supremo Tribunal Federal na Ação Direta de Inconstitucionalidade (ADI) 5526 (2016) e nas Ações Cautelares números 4039 (2015), 4070 (4010) e 4327 (2017), que determinaram o afastamento e até prisões de parlamentares federais entre 2015 e 2017. O trabalho busca discutir se o Supremo Tribunal Federal mantém em aberto uma questão constitucional histórica - a delimitação da sua atuação no tema denominado "questões políticas" - ou optou por justificar o avanço nas atribuições privativas do Congresso Nacional a partir de uma perspectiva moralista.
\end{abstract}

PALAVRAS-CHAVE

Poder Judiciário. Questões políticas. Ativismo judicial. Democracia. Moralismo.

\begin{abstract}
This article examine the "Political question doctrine" within the scope of the Supremo Tribunal Federal (Federal Supreme Court) from a historical view of the matter. Despite the tripartite functions of the State, some historical reasons have led to the current model of constitutional jurisdiction in Brazil, and it is possible to identify that, since the First Republic (1889-1930), the Judiciary has been led to express its limits on its nature. With the promulgation of the 1988 Constitution, under the prism of a new democracy, the Brazilian institutional framework was substantially altered from the new constitutional paradigm, which was assigned a strategic role to the Judiciary, granting it functional autonomy in order to prevent that the law continued to be instrumentalized. Two moments will be analyzed in this work: i) habeas corpus 300 (1892), 1063 (1898), 1073 (1898) and the classic work The Law of the Amazon to the Northern Acre (1910); and (ii) the actions of the Federal Supreme Court in the Direct Action of Unconstitutionality (ADI) 5526 (2016) and in the Precautionary Actions number 4039 (2015), 4070 (4010) and 4327 (2017), which determined the removal and even arrests of members of parliament federal courts between 2015 and 2017. The paper seeks to discuss whether the Federal Supreme Court holds open a historical constitutional issue - delimiting its action on the theme called "political issues" - or has chosen to justify the advance in the exclusive attributions of the National Congress from from a moralistic perspective.
\end{abstract}

\section{KEYWORDS}

Judiciary Branch. Political issues. Judicial activism. Democracy. Moralism.

\footnotetext{
${ }^{*}$ Docente do Programa de Pós-Graduação (mestrado e doutorado) em Direito da Universidade de Fortaleza, do Programa de Mestrado em Direito e Gestão de Conflitos da Universidade de Fortaleza - UNIFOR e professor de Ciência Política do Curso de Direito da mesma universidade. Foi Procurador-Geral do Município de Fortaleza de abril de 2001 a julho de 2004. Doutorado em Direito Constitucional pela Universidade de Fortaleza com doutorado-sanduíche na Boston University, Massachusetts. Pós-doutorado em Ciência Política pela Boston University, Procurador municipal de Fortaleza.

${ }^{*}$ Mestrando em Direito Constitucional pela Universidade de Fortaleza. Pós-Graduado em Direito Tributário. Bacharel em Direto pela Universidade de Fortaleza.
} 


\section{SUMÁRIO}

Introdução. 1. Questões políticas e STF: julgamentos históricos e o caso "O Direito do Amazonas ao Acre Setentrional". 2. A atuação do Supremo Tribunal Federal na ADI 5526, AC 4039, AC 4070 e AC 4327. 3. Questões políticas: moralismo como parâmetro? Conclusão. Referências.

\section{INTRODUÇÃO}

O trabalho busca discutir se o Supremo Tribunal Federal mantém em aberto uma questão constitucional histórica - a delimitação da sua atuação no tema denominado "questões políticas" - ou optou por justificar o avanço nas atribuições privativas do Congresso Nacional a partir de uma perspectiva moralista, essa a questão acadêmica em torno da qual este texto orbita.

Dois momentos históricos distintos e distantes entre si serão examinados no texto: i) em razão da relevância histórica os habeas corpus números 300 (1892), 1063 (1898), 1073 (1898) e a obra clássica $O$ Direito do Amazonas ao Acre Setentrional (1910); e ii) a atuação do Supremo Tribunal Federal na Ação Direta de Inconstitucionalidade (ADI) 5526 (2016) e Ações Cautelares números 4039 (2015), 4070 (4010) e 4327 (2017) que examinam a possibilidade de afastamento de parlamentares por meio de medidas cautelares judiciais e até a prisão de um senador da República.

No Brasil, a trajetória do Estado Democrático de Direito é marcada pela frágil compreensão da articulação entre o Direito e a Política, posto que o fortalecimento e a realização de direitos e garantias aos cidadãos sempre se confrontaram com uma tradição de Executivos personalistas que colocavam interesses políticos acima dos interesses democráticos, tornando o campo da política imune a controles jurídicos.

Tradicionalmente, o direito representou apenas um instrumento para a legitimidade das decisões políticas, atribuindo-se roupagem de legalidade à vontade dos governantes e ficando com um papel secundário, isto é, materialmente dependente da esfera política, possibilitando, assim, uma atuação arbitrária do Executivo e do Legislativo (STRECK; TASSINARI; LIMA, 2013).

A Primeira República (1889-1930) não foi superada para dar espaço à democratização do Estado brasileiro, mas para se submeter a um projeto político autoritário a partir de 1937, em que o tratamento dispensado ao Poder Judiciário não fora diferente do que já havia ocorrido anteriormente, confirmando a existência de um Poder Executivo arbitrário e uma jurisdição constitucional acanhada pelas constantes ameaças de intervenção política.

A redemocratização, em 1946, e o fortalecimento do Poder Judiciário naquela quadra foi interrompida precocemente com o Golpe de 1964, e apenas com a promulgação da Constituição de 1988 o quadro institucional brasileiro foi substancialmente alterado, a partir do novo paradigma constitucional que atribuiu relevante papel estratégico ao Poder Judiciário, conferindo-lhe autonomia funcional com o intuito de impedir que o Direito continuasse a ser instrumentalizado. A transição para o Estado Democrático de Direito aumentou o controle dos atos políticos, atribuindo-se expressamente ao STF o papel institucional de guardião da Constituição, o que lhe permitiu controle sobre as decisões políticas tomadas pelo Poder Executivo, bem como quanto às decisões majoritárias tomadas pelo Parlamento, em razão da garantia da inafastabilidade da tutela jurisdicional.

Questão tormentosa é divisar e distinguir a garantia da inafastabilidade da tutela jurisdicional do fenômeno da judicialização da política que, da perspectiva do Poder Judiciário, seria algo positivo porque fortaleceria a jurisdição (ou poder dos juízes), mas análises críticas têm denunciado 
que o avanço na seara do político favoreceu o surgimento de um sistema de controle de constitucionalidade exacerbado.

Para tanto, na primeira parte do artigo, o caso denominado Direito do Amazonas ao Acre Setentrional e alguns julgamentos históricos (habeas corpus) ilustram o trato da questão no Supremo Tribunal Federal da Primeira República (1891-1930), indicando, já àquela altura, um entendimento cambiante a respeito dos limites de atuação daquela corte. $O$ capítulo seguinte aborda a Ação Direta de Inconstitucionalidade (ADI) 5526 que decidiu ser de competência da Casa Legislativa respectiva o exame sobre o afastamento de parlamentares quando este ato implicar no afastamento de suas atribuições e exercício do mandato, bem como das Ações Cautelares números 4039, 4070 e 4327 que determinaram a prisão do ex-senador Delcídio do Amaral e os afastamentos do ex-deputado Eduardo Cunha e do senador Aécio Neves.

Por fim, o texto traz uma discussão teórica sobre o trato de questões políticas a partir da perspectiva das doutrinas estrangeira e nacional com ênfase nas dificuldades de transpor limites impostos pela Constituição e na utilização de argumentos de cunho moral quando do enfrentamento da questão pelo STF nos dias que correm.

\section{QUESTÕES POLÍTICAS E STF: JULGAMENTOS HISTÓRICOS E O CASO "O DIREITO DO AMAZONAS AO ACRE SETENTRIONAL"}

A atuação do Supremo Tribunal durante a Primeira República (1889-1930) é vista de forma contraditória por juristas, historiadores e cientistas políticos. As opiniões vão da acusação de poder falho, "por não ter exercido os poderes políticos que lhe cabiam como intérprete da Constituição" (KOENER, 1994, p. 60) a poder vacilante, mas que acabou por se tornar o guardião das liberdades ameaçadas. O que existe em comum às duas posições é o reconhecimento da influência externa da política no processo decisório da corte, sendo que, "para a primeira posição, a política teria exercido uma influência negativa permanente sobre os ministros (...) para a segunda posição, a história do STF se caracterizaria pelo reconhecimento pelos demais atores do seu papel de supremo intérprete da Constituição" (KOENER, 1994, p. 60).

Com efeito, o Supremo Tribunal Federal tem tratado o tema das questões políticas, desde a Primeira República (1891-1930) até a atualidade, em um espectro que oscila entre o alheamento e o ativismo judicial puro e simples, ativismo aqui entendido como uma "atitude, decisão ou comportamento dos magistrados no sentido de revisar temas e questões - prima facie - de competência de outras instituições" (VIEIRA, 2009, p. 76-84).

O primeiro caso político submetido ao conhecimento do Supremo Tribunal Federal (TEIXEIRA, 2005) foi o Habeas Corpus $\mathrm{n}^{\mathrm{o}} 300$, de 1892 (BRASIL, 1892) em que a atuação da corte indicou uma posição de alheamento, na medida em que a ação buscava a libertação, durante o estado de sítio, de 46 opositores à Floriano Peixoto, que se recusava a convocar eleições presidenciais após a renúncia de Deodoro da Fonseca. A convocação de novas eleições se justificava porque a renúncia se deu antes de completados dois anos de mandato presidencial e, nos termos do art. 423 da Constituição de 1891, esta deveria ser a conduta. O acórdão relatado por Joaquim da Costa Barradas delimitou a questão:

[...] considerando, portanto, que, antes do juízo político do Congresso, não pode o Poder Judicial apreciar o uso que fez o Presidente da República daquela atribuição constitucional, e que, também, não é da índole do Supremo Tribunal Federal envolver-se nas funções políticas do Poder Executivo ou Legislativo.

Considerando que, ainda quando na situação criada pelo estado de sítio, estejam ou possam estar envolvidos alguns direitos individuais, esta 
circunstância não habilita o Poder Judicial a intervir para nulificar as medidas de segurança decretadas pelo Presidente da República, visto ser impossível isolar esses direitos da questão política, que os envolve e compreende, salvo se unicamente tratar-se de punir os abusos dos agentes subalternos na execução das mesmas medidas, porque a esses agentes não se estende a necessidade do voto político do Congresso.

Esse julgamento inaugurou a doutrina das questões políticas no Supremo Tribunal Federal, indicando posição de completo alheamento ao enfrentamento da questão, vencido o voto de Pisa e Almeida que concedia a ordem e reconhecia a competência daquela corte para libertar os presos e desterrados, inclusive o poeta Olavo Bilac.

A guinada do entendimento se deu em 1897 quando da decretação de estado de sítio em razão da tentativa de assassinato de Prudente de Moraes e a morte do Marechal Carlos Machado Bitencourt, que tentou defender o presidente e sofreu um golpe de punhal, fatos que caracterizaram uma conspiração contra o governo. O estado de sítio foi acatado pelo Congresso e o inquérito apontou como coparticipantes um senador, cinco deputados e outros civis e militares que foram desterrados para a ilha de Fernando de Noronha.

Em março de 1898, Rui Barbosa impetrou o habeas corpus 1.063 pedindo o fim da pena de desterro porque o prazo do estado de sítio havia cessado, argumento semelhante ao de 1892, mas o pedido foi rejeitado por cinco votos contra quatro, reafirmando o Relator Bernardino Ferreira que o Poder Judiciário não poderia examinar as medidas do Presidente da República durante o estado de sítio. No entanto, reconheceu no acórdão a possibilidade da intervenção do Poder Judiciário quando as medidas discricionárias do Presidente da República se afastarem dos limites da Constituição, que não poderia ficar à mercê de dois órgãos da Soberania Nacional.

É relevante destacar que Rui Barbosa, “com sua interpretação extensiva do habeas corpus, já se preocupava com a disponibilidade de ações processuais capazes de fazer valerem os direitos constitucionais" (LYNCH, 2017, p. 995), antecipando o constitucionalismo da efetividade.

Ainda que o Habeas Corpus n ${ }^{\circ} 1063$ não tenha tido êxito, a questão teve desfecho favorável quando do julgamento do Habeas Corpus $\mathrm{n}^{\circ}$ 1073, que foi ajuizado 20 dias depois pelo ministro aposentado Joaquim da Costa Barradas, relator do caso de 1892, e cujos pacientes eram os mesmos do HC de Rui Barbosa. Com nova composição e mudança de voto do ministro Bernardino Ferreira, a ordem foi concedida por nove votos contra quatro, e reconheceu-se que cessariam as medidas de repressão após superado o perigo para a segurança da República.

O terceiro caso paradigmático, e objeto deste estudo, também protagonizado por Rui Barbosa, trata da questão de $O$ Direito do Amazonas ao Acre Setentrional, obra do autor que expõe detalhes sobre a contenda que nunca foi efetivamente julgada pelo STF. Com efeito, diante da abundância da seringueira e do ciclo da borracha que estava se iniciando, colonos brasileiros iniciaram a ocupação do Acre - até então território boliviano -, o que ocasionou o envio do exército por parte da Bolívia para retomada do seu território, causando, em 1899, uma revolta armada dos colonos brasileiros que receberam o apoio do Governo do Estado do Amazonas. Após intervenções diplomáticas por parte da Bolívia, mas antes que os ânimos se acirrassem, a diplomacia brasileira comandada pelo Barão do Rio Branco assinou, em 17 de novembro de 1903, entre os governos do Brasil e da Bolívia, o Tratado de Petrópolis, integrando, assim, o Acre ao território brasileiro.

O Estado do Amazonas reagiu por meio de um mandado de segurança patrocinado por Rui Barbosa em que reivindicava perante o Supremo Tribunal Federal, em face da União, o direito sobre o território acreano, uma vez que, pelo Tratado de Petrópolis entre o Brasil e a Bolívia, o Território do Acre ficou sob a administração 
federal. Defendia Rui Barbosa que, considerando que o Acre Setentrional sempre foi havido por território do Amazonas, em cuja posse e jurisdição sempre exercera, quer durante o regime imperial ou mesmo na República, a Constituição da República Estados Unidos do Brasil, assim por ele chamado, não concedia outra atribuição ao Congresso Nacional que não fosse a de aprovar, ou não, as alterações de limites livremente acordadas entre os Estados, não permitindo intervenção que sobejasse esse tema.

A narrativa de Rui indica que em busca de reparação judiciária o primeiro obstáculo que tropeçara foi a razão e a política invocadas pelos interesses do abuso contra o curso do remédio constitucional. Admite o jurista que desde Marshall a jurisdição dos tribunais contra o exercício inconstitucional das faculdades do Governo, ou do Congresso, ficou reconhecido existir no domínio desses poderes uma região impenetrável à autoridade da justiça: a região da política.

$\mathrm{Na}$ defesa dos interesses do Amazonas, sustentou que o Judiciário não poderia se furtar de apreciar causas cujo conteúdo fosse político, levantando duas razões: i) por se tratar o STF de uma Corte Política; e, ii) porque questões dessa natureza eram socialmente relevantes e, portanto, mereciam passar pelo crivo do Poder Judiciário. As razões apresentadas trouxeram um estudo minucioso sobre arestos norte-americanos que também versavam sobre questões políticas e que foram decididos pela Suprema Corte dos Estados Unidos da América, a exemplo do famoso caso Marbury v. Madson, dentre outros (BARBOSA, 1983).

Da análise apresentada, verificou-se que a orientação da jurisprudência na Corte Suprema norte-americana variou notoriamente com as convicções e relações políticas dos juízes, encontrando-se nas decisões de inconstitucionalidades uma relevante criação legislativa. No entanto, a Corte norte-americana sempre sustentou não lhe ser lícito "intervir no exercício político do poder da legislatura, ou do Presidente", e que não poderia constituir objeto de litígio perante ela "as questões políticas de sua natureza” (BARBOSA, 1983, p. 110).

$\mathrm{Na}$ tentativa de convencer o Supremo Tribunal Federal brasileiro de um entendimento contrário, o jurista advogou que não bastaria ser a questão estreme com a política, ou com ela ter relações políticas, ou mesmo ser suscetível de efeitos políticos. Seria relevante que fosse simples, pura e meramente política, isto é, que pertencesse ao domínio político total, única, privativa, exclusiva e absolutamente. Só, então, cessaria a competência judicial (BARBOSA, 1983). Rui Barbosa (1983) apresentou tese contraposta, sustentando que onde quer que surja um problema jurídico, embora não fosse estreme de elementos políticos, teria que receber a solução legal do poder constituído para dar efeito às garantias constitucionais. Para tanto, citou dois exemplos: o dos tratados internacionais e o da legislação tributária.

No primeiro caso não existiria esfera mais eminentemente política do que a das convenções internacionais, mas considerando que os tratados são recepcionados pela legislação local como lei, estes poderiam ser anulados pelos Tribunais, tendo assentado como noção trivial esta subordinação à Constituição (BARBOSA, 1983). No tocante à legislação de impostos, o poder tributário evidentemente não seria judicial, mas legislativo, em que o legislador teria como discricionariedade o eleger da matéria tributável, o decidir entre as considerações de conveniência, necessidade e equidade na seleção, incidência e gravidade dos tributos, não sendo permitido recurso contra eventual inconveniência, iniquidade ou excesso. No entanto, necessário seria que obedecesse estritamente às condições naturais da legislação tributária, na forma e na substância, observando os ditames constitucionais sob pena de ver judicializada a matéria. 
Assim, a ação proposta pelo Estado do Amazonas versava exatamente contra um Decreto Legislativo e um Decreto Administrativo de 1904, que na visão do autor havia violado o direito que a Constituição assegurara à parte do Acre Setentrional, haja vista que esse território pertenceria àquele Estado sob o regime imperial e permaneceu durante o regime republicano, tendo o governo e o legislativo infringido a Constituição da República.

Inobstante toda a discussão jurídica provocada pelo Estado do Amazonas, o desfecho foi melancólico e "não chegou a ser decidido pelo Supremo Tribunal Federal" (BARBOSA, 1983, p. LXXXII). Até 1934, a questão não foi enfrentada e somente após a promulgação daquela Constituição (Art. 5. Das Disposições Transitórias) a pendência foi remetida ao arbitramento e ainda levou quase duas décadas para o Estado do Amazonas solicitar a indenização pela desanexação do Acre.

\section{A ATUAÇÃO DO SUPREMO TRIBUNAL FEDERAL NA ADI 5526, AC 4039, AC 4070 E AC 4327}

Após mais de um século da discussão de Rui Barbosa, intervalo de tempo no qual não cessaram as discussões sobre questões políticas no Poder Judiciário, o Supremo Tribunal Federal foi instado a se manifestar por meio da Ação Direta de Inconstitucionalidade (ADI) 5526 acerca da possibilidade de afastamento de parlamentares por medidas cautelares judiciais. A ação foi movida em maio de 2016 pelos partidos PP, PSC e Solidariedade, pois consideraram a Câmara e o Senado os foros competentes para deliberar sobre tais medidas.

A discussão acerca da matéria teve como causa a decisão do STF, em 2016, por meio da Ação Cautelar (AC) 4070, de afastar o exdeputado Eduardo Cunha da Presidência da Câmara dos Deputados e de suas funções parlamentares em razão de atos de corrupção apurados pelo Ministério Público Federal e em depoimentos na Comissão de Ética daquela casa.

A segunda turma do Supremo Tribunal Federal já havia se manifestado, em 2015, ao julgar a Ação Cautelar (AC) 4039, ajuizada pelo Ministério Público Federal (MPF), mantendo a decisão concedida pelo Ministro Teori Zavascki que decretou a prisão preventiva do senador Delcídio do Amaral, bem como determinou a comunicação, em 24 horas, ao Senado Federal, para que a prisão fosse decidida naquela Casa Legislativa pelo voto da maioria de seus membros, conforme destacado no Artigo 53, parágrafo $2^{\circ}$, da Constituição Federal.

$\mathrm{O}$ entendimento que preponderou na segunda turma do STF, para manter a decisão do então Ministro Teori Zavascki, foi o de que o crime permanente (integrar crime organizado) admite o flagrante, assim como os reprováveis atos imputados ao senador são causa de decretação de prisão preventiva. Logo, estariam atendidos os requisitos constitucionais (Art. 53, $\left.\S 2^{\circ} \mathrm{da} C F\right)$.

Em outro caso relevante para a discussão posta neste texto, a primeira turma do STF na Ação Cautelar (AC) n 4327, de 2017, determinou a suspensão do exercício das funções parlamentares, ou de qualquer outra função pública, do senador Aécio Neves, além de determinar-lhe o recolhimento domiciliar noturno em razão de inquérito em que o parlamentar era investigado a partir das colaborações premiadas no âmbito da denominada Operação Lava Jato.

Apenas 15 dias após a imposição de medidas cautelares alternativas ao senador Aécio Neves, o Plenário da Corte decidiu, por maioria, julgar parcialmente procedente a ADI 5526, assentando que compete à Casa Legislativa a que pertence o parlamentar a decisão pela qual se aplica medida cautelar para afastá-lo de suas atribuições, sempre que a execução da medida 
acautelatória impossibilitar, direta ou indiretamente, o exercício regular de mandato.

Assim, o cerne da questão versou sobre a possibilidade de o Poder Judiciário intervir na atividade parlamentar de um agente político eleito pelo sufrágio universal, retirando de uma determinada parcela da população sua representatividade. Com efeito, apesar da previsão de afastamento de parlamentar em situações excepcionalíssimas, a Constituição Federal foi categórica no tocante a perda de mandato por condenação criminal transitada em julgado, ocasião em que a Lei Maior foi explícita ao estabelecer o dever de pronunciamento da casa parlamentar respectiva (Art. 55, $\S 2^{\circ}$ ).

O episódio envolvendo o senador Aécio Neves, em que o STF reconheceu a competência da respectiva Casa Legislativa para decidir sobre o afastamento ou não do parlamentar, poderia apontar para um retorno à autocontenção judicial (judicial self restraint), posicionamento cada vez mais episódico nos dias que correm apesar de uma consistente doutrina que defende a autolimitação judicial, mas a reflexão teórica que segue aponta para caminho oposto, o da utilização de padrões moralistas para justificar atuação da corte em episódios com grande repercussão social.

\section{QUESTÕES POLÍTICAS: MORALISMO COMO PARÂMETRO?}

Os limites da atuação do Supremo Tribunal Federal em questões políticas, de uma perspectiva histórica, apontam que nos primeiros anos da República (e de atuação do STF) houve uma atitude de alheamento da Corte no exame dos habeas corpus que buscavam a garantia de direitos individuais. Apenas em 1898 a corte reconheceu que direitos individuais não podem ficar à mercê de medidas políticas (TEIXEIRA, 2005) e essa decisão delimitou o marco inicial da fase de consolidação da doutrina (1910-1930).
Em 1951, anota Teixeira, o STF recorreu a uma nova fórmula, a de que "não é a natureza essencialmente política da questão que deve definir se uma causa está ou não sujeita ao conhecimento do Tribunal", mas, sim, "se os argumentos articulados estão vinculados a aspectos relativos à conveniência, oportunidade ou acerto do ato político" (TEIXEIRA, 2005, p. 232).

Entretanto, foi na década de 1980 que o STF adotou a matéria interna corporis como critério de não-intervenção em Casas Legislativas, na esteira histórica do processo de abertura política que atravessava o país. Em seguida, já na década de 1990, a tese foi reafirmada ao reconhecer que as normas regimentais não gerariam direitos subjetivos que garantissem a atuação do Judiciário, ainda em relação a discussões travadas no âmbito do Poder Legislativo.

Entre 2015 e 2017, o STF atuou em três episódios marcantes da vida política nacional, todos envolvendo afastamento ou prisão de parlamentares no exercício de mandatos: em 2015 (AC 4039), determinou a prisão do então senador Delcídio Amaral; em 2016 (AC 4070), o STF determinou o afastamento do mandato do deputado Eduardo Cunha, então Presidente da Câmara dos Deputados; e, em 2017 (AC 4327), a Corte impôs a suspensão das funções parlamentares do senador Aécio Neves, inclusive com medida de recolhimento domiciliar, entrega de passaportes e proibição de manter contato com outros investigados.

Esta última medida foi mitigada quando do julgamento da ADI 5526, que reconheceu a competência das Casas Legislativas para decidirem sobre as medidas cautelares impostas pelo STF sempre que a execução desta impossibilitar, direta ou indiretamente, o exercício regular de mandato parlamentar, apenas 15 dias após a decisão na $\mathrm{AC}$ 4327. Uma indagação neste momento se impõe: a guinada no posicionamento do STF no intervalo de duas 
semanas implicou na adoção de uma tendência à autocontenção judicial? Ou o recuo no afastamento de parlamentares por decisão judicial com fundamento em dispositivo do Código de Processo Penal (medida cautelar) foi circunstancial e estratégico em razão de pressões políticas?

As doutrinas nacional e estrangeira ao tratarem da imposição de limites à atuação do Poder Judiciário em questões políticas têm densidade e tradição. Canotilho (2000, p. 1224) defende que o princípio da autolimitação judicial consiste no fato de que "os juízes devem autolimitar-se à decisão de questões jurisdicionais e negar a justiciabilidade das questões políticas"; Richard Posner (2007) aponta para o entendimento de que a autoconstrição judicial é uma teoria política e não um resultado de raciocínio jurídico. $\mathrm{Na}$ mesma linha de pensamento, Antonio Umberto de Souza Júnior (2004) entende que a autocontenção judicial parece mais próxima da corrente que prioriza a vitalidade da democracia.

A doutrina sempre apontou que ao Poder Judiciário somente caberia avaliar se um caso é ou não exclusivamente político, estando "préfixadas" na Constituição de 1988 que o constituinte reservou um caráter nitidamente político. Martonio Mont'Alverne Barreto Lima (2006), comentando a opinião de Paulo Brossad, entende que o fato de o constituinte excluir da apreciação do Poder Judiciário determinadas situações é uma fiel obediência à teoria da democracia, pois situações devem ser entregues ao Poder Legislativo em razão de sua legitimidade política.

$\mathrm{O}$ agigantamento do Judiciário foi analisado no constitucionalismo alemão, na obra de Ingeborg Maus (2000) intitulada O Judiciário como superego da sociedade órfã, na qual a jurista recorreu a conceitos de psicologia para explicar - em analogia à figura do pai que representa o superego do filho - que as instituições políticas eram responsáveis por organizar a sociedade, mas que a partir da crise democrática e da desconfiança em relação às clássicas instituições políticas, a sociedade viu-se "órfã", razão pela qual sentiu necessidade de procurar novo gestor da vida em sociedade, novo superego: o Judiciário (MAUS, 2010).

Jonh Hart Ely (1996), fazendo a distinção entre as questões jurídicas e políticas, publicou seu ensaio Democracy and distrust no qual demonstrou a ilegalidade da atuação dos juízes quando do enfrentamento das questões políticas por falta de legitimidade, tendo em vista que não foram eleitos pelo povo e não poderiam governar conforme bem entendessem. $\mathrm{O}$ autor trouxe como tese fundamental a existência de um limite na interpretação dos juízes, no que tange as disposições abertas da Constituição, optando pela democracia.

Ronald Dworkin (2005), recorrendo à figura do juiz Hércules e ao construtivismo jurídico para apoiar as suas teorias, bem como às clássicas diferenças entre regras e princípios, apresentou uma contribuição substancialista definindo a atuação das cortes constitucionais. $\mathrm{O}$ ponto alto da ideia de direito como integridade está na divisão que Dworkin (2005) estabeleceu entre argumentos de princípio político e argumentos de procedimento político. $\mathrm{O}$ autor entendeu que o legislador pode decidir com base em argumentos de princípio político e em argumentos de procedimento político. $\mathrm{O}$ juiz, por sua vez, diante de um caso controverso pode e deve decidir com base em argumentos de princípio político, mas nunca invocando argumentos de procedimento político.

Ronald Dworkin (2002) tentou definir o que são questões políticas, diferenciando-as de princípios, no sentido de que caberia aos Tribunais apenas decisões baseadas em princípios:

[...] los argumentos políticos justifican una decisión política demostrando que favorece o protege alguna 
meta colectiva de la comunidad en cuanto todo. El argumento en favor de un subsidio para los fabricantes de aviones, que afirma que con él se protegerá la defensa nacional, es un argumento político. Los argumentos de principio justifican una decisión política demostrando que tal decisión respeta o asegura algún derecho, individual o del grupo. El argumento a favor de las leyes que se oponen a la discriminación (racial en los Estados Unidos), y que sostiene que una minoría tiene derecho a igual consideración y respeto, es un argumento de principio (DWORKIN, 2002, p. 148).

Habermas (1997), apresentando uma sugestão procedimentalista para atuação das cortes constitucionais, indicou que os debates deveriam ser realizados no âmbito da comunidade dos intérpretes da Constituição; o entendimento resultaria em um ambiente discursivo, do qual sobressairia o melhor argumento. Estas situações dialógicas envolveriam três elementos: a ausência de óbices à participação dos cidadãos, a ausência de violência durante as sessões, e a seriedade, que seria a busca cooperativa pelo acordo. Habermas conseguiu aliar o procedimentalismo de Jonh Hart com o modelo de Dworkin, substituindo o juiz Hércules pela sociedade aberta dos intérpretes da Constituição. A proposta de Habermas é criticada por se mostrar viável em países onde se possa falar de uma cultura comunitária; já nos países subdesenvolvidos, referida proposta seria inviável (SOUZA JÚNIOR, 2004).

O autor francês Antoine Garapon (1999), em sua obra $O$ juiz e a democracia: o guardião das promessas, apontou que a extensão do controle do juiz quase sempre vem de uma delegação do próprio poder político, afirmando que essa resposta se encontra na própria extensão da competência da justiça e, ainda, na judicialização do discurso político. Na concepção de Garapon, o juiz se tornou um "guardião de promessas", sendo instado a decidir os mais diversos temas, entregando ao juiz a responsabilidade de sanar os conflitos privados e públicos dos mais diversos, tornando-o, assim, um remédio para todos os males, fazendo com que o Judiciário encontre uma forma de pacificação social que, muitas vezes, não está ao seu alcance.

Nos casos referidos nesta reflexão teórica, o STF, entre 2015 e 2017, afastou o Presidente da Câmara dos Deputados, determinou a prisão de um senador da República e afastou do exercício do mandato um outro senador. Em que pese a trajetória nada recomendada dos três parlamentares, marcadas por denúncias, grampos telefônicos e envolvimento, direta ou indiretamente, em investigações em curso, verifica-se uma tendência da imposição de fundamentação moral em detrimento da literalidade da Constituição. É tema que foge ao escopo deste escrito, mas já existe uma maioria prestes a se consolidar no STF no sentido de afastar a "literalidade" da presunção de inocência como forma de combate à impunidade - não é demais lembrar.

Nos dias que correm, o STF parece justificar (fundamentar) incursões em questões políticas a partir de argumentos de cunho moral, não mais recorrendo ao limite interna corporis ou reconhecendo que as normas regimentais não geram direitos subjetivos como critérios de nãointervenção em Casas Legislativas. A questão da impunidade tem se transformado em senha para o avanço sobre prerrogativas constitucionais a partir de uma indignação expressada em votos carregados de advertências moralistas. Não com isso que as decisões sejam proferidas sem fundamentação jurídica; existe uma discussão jurídica, quase nunca unânime e quase sempre polêmica, mas nos casos aqui discutidos a decisão parece ser tomada a partir de motivações pessoais de membros da Corte que, se não utilizadas como fundamento jurídico (porque é moral), deixa entrever quando da construção do argumento.

$\mathrm{Na} \mathrm{AC} 4039$, que determinou a prisão do senador Delcídio do Amaral, o voto do MinistroRelator Teori Zavascki é técnico, ainda que adote tese controversa do estado de flagrância para 
justificar a prisão do senador e faça a ressalva do caráter excepcional daquele posicionamento. A decisão adota, no entanto, como uma das razões de decidir um trecho do voto da Ministra Carmen Lúcia no HC 89417, de 2006, em que se lê:

[...] tal como a quimioterapia impõe que se agridam células boas para atingir e exterminar células más, a fim de salvar o corpo doente, assim também, repito o quanto antes afirmei: haverá de haver remédio jurídico, sempre, a garantir que o corpo normativo fundamental não se deixe abater pela ação de uma doença que contraria a saúde ética e jurídica das instituições e que pode pôr a perder todo o sistema constitucional.

A metáfora da corrupção como um câncer que deve ser extirpado é manifesta, e busca justificar medidas extremas para a preservação do corpo normativo, ainda que o remédio seja um desvio na integridade desse mesmo "corpo normativo". No julgamento da AC 4039, a ministra Carmen Lúcia declarou que "o crime não vencerá a Justiça" e advertiu: "um aviso aos navegantes dessas águas turvas de corrupção e iniquidades: criminosos não passarão a navalha da desfaçatez e da confusão entre imunidade e impunidade e corrupção. Em nenhuma passagem, a Constituição Federal permite a impunidade de quem quer que seja".

Na AC 4070 (caso Eduardo Cunha), também relatado pelo Ministro Teori Zavascki, novamente um trecho de voto da ministra Carmen Lúcia no HC 89.417 é transcrito (parte final):

[...] aplicar como pretende o Impetrante a norma do art. $53, \S \S 2^{\circ}$ e $3^{\circ}$ da Constituição, quer dizer, como espaço jurídico que impede que o Poder Público cumpra a sua obrigação para chegar à apuração, e, se for o caso, à eventual punição de alguns pela proibição de adotar as providências devidas para se chegar ao fim do direito, além de se impedir que se extinga o ambiente institucional contaminado por práticas que podem se mostrar delituosas e ao possível cometimento de infrações que se vêm perpetrando no ente federado, simplesmente porque não se pode aplicar o direito, seria chegar à mesma equação de ineficácia já narrada em numerosas passagens literárias. Mas a vida não é ficção e a moral e o direito não hão de ser histórias para ser contadas sem compromisso com a eficácia.

O relator da AC 4070 ainda conclui que se trata de

[...] uma situação extraordinária, excepcional e, por isso, pontual e individualizada. A sintaxe do direito nunca estará completa na solidão dos textos, nem jamais poderá ser negativada pela imprevisão dos fatos. Pelo contrário, o imponderável é que legitima os avanços civilizatórios endossados pelas mãos da justiça. Mesmo que não haja previsão específica, com assento constitucional, a respeito do afastamento, pela jurisdição criminal, de parlamentares do exercício de seu mandato, ou a imposição de afastamento do Presidente da Câmara.

Na AC 4327 AgR - Terceiro - AgR/DF (caso Aécio Neves), o STF denegou a prisão preventiva, mas determinou a aplicação de medidas cautelares, posteriormente revistas em sede de controle de constitucionalidade (ADI 5526) ao reconhecer que pertence à Casa Legislativa a que pertence o parlamentar decidir sobre o seu afastamento sempre que a medida cautelar impossibilite o exercício regular do mandato. Ainda assim, é possível colher da ementa do julgamento que "a imunidade formal quanto ao processo e quanto à prisão, ex vi do art. $53, \S \S 2^{\circ}$ e $3^{\circ}$, da Carta Fundamental de 1988 , pode ser excepcionada sempre que se verificar, à luz das circunstâncias do caso concreto, que sua interpretação conduziria a um cenário de inefetividade do sistema constitucional. Jurisprudência: HC 89.417, Relator(a): Min. CÁRMEN LÚCIA, Primeira Turma, julgado em 22/08/2006".

No voto do ministro Luiz Fux extraem-se passagens que indicam uma indignação moral com os fatos postos:

Senhor Presidente, se há um sentimento que não me
assoma agora é efetivamente esse sentimento mais
suave e mais leve que Vossa Excelência procura
imprimir. Eu nunca pensei que fosse ocupar este
lugar para apreciar uma questão em torno de uma
pessoa querida, com quem eu não tenho intimidade,
mas que sempre apreciei. De toda sorte,
recentemente revelou um inequívoco apoio popular, 
por meio de uma eleição expressiva para Presidente da República.

E continua o ministro Fux:

Eu aprecio este caso à luz de visões interdisciplinares. Um dos maiores expoentes, para mim, na política do Brasil, o Presidente Fernando Henrique Cardoso, em um desabafo, porquanto ocupa uma posição de proeminência no Partido, assentou aquilo que é o nosso sentimento: realmente, o Senador foi alvejado de maneira grave, por tanto quanto se ouviu e se leu do processo.

\section{E mais a frente:}

De sorte, Senhor Presidente, isso tudo se resume num gesto de grandeza que o homem público deveria ter adotado. Já que ele não teve esse gesto de grandeza, nós vamos auxiliá-lo para que, exatamente, ele se porte tal como deveria se portar; pedir não só para sair da presidência do PSDB, pedir uma licença, sair do Senado Federal para poder comprovar, à saciedade, a sua ausência de toda e qualquer culpa nesse episódio, que acabou marcando, de maneira dramática, para nós que convivemos com ele, a sua carreira política.

A metáfora do câncer, da Justiça vencendo o crime, de navegantes de águas turvas de corrupção e iniquidades, o veto da Constituição em relação à impunidade de quem quer que seja, aliados a sentimentos de perplexidade, podem ser um indicativo de o STF avançando em temas de competência exclusiva do Congresso Nacional, sob a justificativa de cunho moral, em detrimento da literalidade da Constituição ou da interpretação constitucional assentada.

É como se fosse necessário carregar nas tintas da moralidade ou do discurso inflamado para justificar uma decisão que afronta diretamente a Constituição, seja porque não há previsão legal de afastamento do Presidente da Câmara dos Deputados (ou do Senado) por ato do Poder Judiciário - hipótese reconhecida como inexistente -, seja porque a aplicação de medidas cautelares de recolhimento noturno ou de frequentar o gabinete de trabalho não parecem se enquadrar na espécie normativa do afastamento de agente público da função.

\section{CONCLUSÃO}

O Supremo Tribunal Federal não definiu, até os dias de hoje, o seu limite de atuação nas "questões políticas", mas pareceu exibir - nos anos 2015, 2016 e 2017 - uma tendência de interferência em assuntos de competência do Poder Legislativo, a partir de uma perspectiva moralista.

A discussão jurídica provocada pelo caso "O Direito do Amazonas ao Acre Setentrional" buscou demonstrar que não ficou definido, naquela época, quais eram as questões verdadeiramente políticas, ou que questões deveriam ser submetidas à tutela jurisdicional. A temática permaneceu indefinida na década de 1950, quando o STF adotou fórmula que analisa se os argumentos articulados estão vinculados ou não à conveniência, oportunidade ou acerto do ato político. Já na década de 1980 a matéria interna corporis passou a prevalecer como critério de não-intervenção em decisões de Casas Legislativas.

Na década de 1990, a tese foi reafirmada ao se reconhecer que as normas regimentais não gerariam direitos subjetivos que garantissem a atuação do Judiciário em relação a discussões travadas no âmbito do Poder Legislativo. Nas primeiras décadas do século XXI, as decisões envolvendo prisão preventiva e afastamento cautelar de parlamentares federais nos anos 2015, 2016 e 2017 trouxeram à tona a discussão dos limites de atuação do STF.

A sequência de decisões analisadas ocorreu em um ambiente de grande agitação política, em período imediatamente anterior ou logo após a deposição da Presidente Dilma Rousseff e no curso da operação denominada Lava Jato, em que parcela considerável da sociedade acompanhava as prisões de empresários e agentes públicos, bem como o afastamento e a prisão de parlamentares e assistia, ao vivo, as sessões de julgamento do 
plenário do STF. Nesses três anos que este texto delimitou a segunda parte da análise, viu-se a prisão em flagrante de um senador da República, o afastamento do Presidente da Câmara dos Deputados, a cassação e posterior prisão do exparlamentar, e o breve afastamento de um senador que havia concorrido à Presidência da República e perdeu por margem apertada de votos em 2014.

O posicionamento do STF nos três casos, ainda que tenha havido o arrefecimento da imposição de medidas cautelares de afastamento do mandato do senador Aécio Neves, tendeu à ampla intervenção em assuntos tradicionalmente de competência do Poder Legislativo (afastamento e prisão de parlamentares), não dando mostras o plenário da Corte a qualquer tendência de autocontenção judicial, apenas reconhecendo que o afastamento cautelar, quando afetasse direta ou indiretamente o mandato, deveria ser apreciado pela respectiva Casa Legislativa.

As doutrinas nacional e estrangeira têm sólidos posicionamentos no sentido de limitar a atuação do Poder Judiciário em matéria de questões políticas, mas verificou-se uma tendência à expansão do poder judicial em todo o mundo traduzida em crescente judicialização da política (estrutural) ou ativismo judicial (comportamental).

A atuação de ministros do STF nos casos em exame, para justificar justiciabilidade em questões políticas e de competência exclusiva de outro poder, parecem tomar argumentos moralistas em detrimento da interpretação constitucional ou até mesmo da literalidade da
Constituição, contornada com o emprego de expressões como excepcionalíssima, singular, pontual, individualizada ou até inusitada, a justificar a não aplicação do texto constitucional ao caso concreto.

A questão do moralismo como critério diverso do texto da Constituição seria impulsionada por uma cruzada contra a impunidade, que se transformaria em justificativa para avanços sobre prerrogativas constitucionais. $\mathrm{Na}$ fundamentação extrajurídica dos extensos votos lê-se analogias com doenças físicas (câncer), utilização de remédios jurídicos, extirpação da corrupção e outras figuras de linguagem que parecem traduzir o ânimo do julgador quando da tomada de decisão, em alguns casos, avançando sobre a Constituição.

Em uma passagem do julgamento da AC 4039, a Constituição chega a ser invocada em tom dramático para se dizer que o texto não autoriza a impunidade de quem quer que seja. É patente que a Constituição não pode autorizar impunidade, sendo que o que se exige, e a Constituição impõe, é o cumprimento dos ritos impostos no texto quando do afastamento ou da prisão de parlamentares, por exemplo.

A temática das questões políticas parece enfrentar um novo desafio: afastar o critério moral como justificativa do avanço sobre temas que até poucos anos atrás eram intransponíveis, uma vez que o guardião da Constituição não pode desempenhar seu relevante papel a partir de critérios havidos fora da Constituição que deve guardar.

\section{REFERÊNCIAS}

BARBOSA, Rui. Obras completas de Rui Barbosa: o direito do Amazonas ao Acre setentrional. v. XXXVII. tomo V. Rio de Janeiro: Fundação Casa de Rui Barbosa, 1983.

BRASIL. Superior Tribunal Federal. Acórdão no Habeas Corpus no 300, de 30 de abril de 1892. Disponível em: http://www.stf.gov.br. Acesso em: 5 abr. 2018. 
CANOTILHO, J.J. Gomes. Direito Constitucional e Teoria da Constituição. 2. ed. Coimbra: Almedina, 1998.

DWORKIN, Ronald. Uma Questão de Princípio. Trad. Luís Carlos Borges. São Paulo: Martins Fontes, 2005.

. Levando os Direitos a Sério. São Paulo: Martins Fontes, 2002.

GARAPON, Antoine. O Juiz e a Democracia: o guardião das promessas. 2. ed. Rio de Janeiro: Revan, 1999.

ELY, H. L. A. O Conceito de Direito. Trad. A. Ribeiro Menezes. 2. ed. Lisboa: Calouste Gulbenkian, 1996.

HABERMAS, Jürgen. Direito e Democracia: entre faticidade e validade. Rio de Janeiro: Tempo Brasileiro, 1997.

KOERNER, Andrei. O poder Judiciário no sistema político da primeira república. Revista USP, (21), 58-69.

LIMA, Martonio Mont'Alverne Barreto. Judicialização da política e comissões parlamentares de inquérito - um problema da teoria constitucional da democracia. Revista da FIC, Fortaleza, v. 4, n. 7 , p. 09-22, 2006.

LYNCH, Christian Edward Cyril; MENDONÇA, José Vicente Santos. Por uma história constitucional brasileira: uma crítica pontual à doutrina da efetividade. Revista Direito e Praxis, Rio de Janeiro, v. 08, n. 2, p. 974-1007, 2017.

MAUS, Ingeborg. O Judiciário como superego da sociedade: o papel da atividade jurisprudencial na "sociedade órfã". Trad. Martônio Lima e Paulo Albuquerque. Revista Novos Estudos CEBRAP, n. 58, p. 183-202, nov. 2000.

. Judiciário como superego da sociedade: do Estado de Direito ao Estado Constitucional da Crítica da Obstrução Jurídica da Democracia. Trad. Geraldo de Carvalho e Gercélia Batista de Oliveira Mendes. Rio de Janeiro: Lumem Juris, 2010.

POSNER, Richard A. Problemas de filosofia do direito. Trad. Jefferson Luiz Camargo. São Paulo: Martins Fontes, 2007.

SOUZA JÚNIOR, Antonio Umberto de. O Supremo Tribunal Federal e as questões políticas: o dilema brasileiro entre o ativismo e a autocontenção no exame judicial das questões políticas. Porto Alegre: Síntese, 2004.

STRECK, Lenio Luiz; TASSINARI, Clarissa; LIMA, Danilo Pereira. A relação direito e política: uma análise da atuação do judiciário na história brasileira. Pensar (UNIFOR), v. 18, n. 3, p. 739-760, set./dez. 2013.

TEIXEIRA, José Elaeres Marques. A doutrina das questões políticas no Supremo Tribunal Federal. Porto Alegre: Sérgio Antônio Fabris, 2005. 
VIEIRA, J. R. O Supremo Tribunal Federal como arquiteto institucional: a judicialização da política e o ativismo judicial. Versus: Revista de Ciências Sociais Aplicadas do CCJE/UFRJ, v. 2, p. 76-84, 2009.

Recebido em: 09/07/2018

Aceito em: 11/08/2018 
